\title{
Kekerasan Dalam Pernikahan Siri: Kekerasan dalam Rumah Tangga? (Antara Yurisprudensi dan Keyakinan Hakim)
}

\author{
Siti Nurhikmah, Sofyan Nur \\ Fakultas Hukum, Universitas Jambi \\ Author's email correspondence: sitinurhikmah158@gmail.com
}

\begin{abstract}
ABSTRAK
Penelitian ini bertujuan untuk mengetahui dan menganalisis penerapan hukum dalam kasus kekerasan dalam rumah tangga. Undang-Undang Penghapusan Kekerasan Dalam Rumah Tangga tidak menyatakan secara eksplisit bahwa kekerasan dalam rumah tangga adalah masalah publik, akan tetapi dengan adanya campur tangan negara mengindikasikan bahwa kekerasan dalam rumah tangga adalah urusan publik. Penelitian ini bersifat yuridis empiris. Dari hasil penelitian menunjukan bahwa ada kasus kekerasan dalam rumah tangga yang terjadi disebabkan oleh kekerasan fisik yang dilakukan oleh suami terhadap istri siri. Pernikahan siri, yang secara agama dianggap sah, pada kenyataannya justru bisa memunculkan banyak sekali permasalahan yang berimbas pada kerugian di pihak perempuan sebagai istri siri, termasuk jika terjadi tindakan kekerasan dalam rumah tangga. Dalam kasus kekerasan dalam rumah tangga yang dilakukan seorang suami terhadap istri siri, akibat hukumnya adalah istri siri itu tidak mendapatkan perlindungan hukum sesuai ketentuan dalam Undang-Undang Penghapusan Kekerasan Dalam Rumah Tangga.
\end{abstract}

\section{ARTICLE HISTORY}

Submission: 12 December 2020

Accepted: 03 February 2020

Publish: 07 February 2020

KEYWORDS: analyze the application of law; criminal act; domestic violence cases

\begin{abstract}
This research aims to determine and analyze the application of law in domestic violence cases. Law on the Elimination of Domestic Violence does not explicitly state that domestic violence is a public problem, but the presence of state interference indicates that domestic violence is a public concern. This research is empirical. The results of the study showed that there were cases of domestic violence that occurred due to physical violence committed by the husband against his wife in undocumented marriage. Its considered religiously legal, in fact can actually lead to a lot of problems that have an impact on the loss on the part of women as undocumenting marriage wives, including if acts of domestic violence. In cases of domestic violence perpetrated by a husband against wife. The legal consequence is that the serial wife does not receive legal protection in accordance with the provisions in the Law on the Elimination of Domestic Violence.
\end{abstract}

\section{A. Pendahuluan}

Kekerasan dalam rumah tangga sebenarnya bukan merupakan hal yang baru. Namun, selama ini selalu dirahasiakan atau ditutup-tutupi oleh keluarga, maupun oleh korban sendiri. Kekerasan yang terjadi dalam rumah tangga mengandung sesuatu yang 
spesifik atau khusus. Kekhususan tersebut terletak pada hubungan antara pelaku dan korban, yaitu hubungan kekeluargaan atau hubungan pekerjaan (majikan-pembantu rumah tangga). Selain itu locus delicti pada kekerasan dalam rumah tangga lebih spesifik, yaitu di dalam rumah, dimana pelaku dan korban bertempat tinggal. Dalam tindak pidana yang lain, locus delicti biasa dimana saja, disemua tempat. ${ }^{1}$

Kekerasan terhadap istri yang dilakukan oleh suami sangat banyak terjadi dalam kehidupan masyarakat namun selama ini terkadang dirahasiakan atau tertutup-tutupi oleh keluarga, maupun oleh korban sendiri. Disamping itu budaya masyarakat ikut berperan dalam hal ini karena masyarakat menganggap bahwa masalah yang terjadi di dalam lingkup rumah tangga adalah masalah atau urusan suami-istri sehingga konflik yang terjadi dalam keluarga dianggap sebagai suatu hal yang biasa dan tidak boleh dicampuri orang lain. Disamping itu bentuk-bentuk kekerasan yang terjadi dalam rumah tangga seperti pemukulan terhadap isteri oleh suami adalah hal yang sangat sulit diungkap, karena persoalannya dianggap sebagai urusan pribadi. Kekerasan dalam rumah tangga mengandung sesuatu yang spesifik atau khusus. Kekhususan tersebut terletak pada hubungan antara korban dan pelaku, yaitu hubungan kekeluargaan dan juga meluas dari itu.

Kelemahan struktur biologis perempuan menempatkannya pada posisi yang marginal dalam masyarakat. Perempuan dianggap tidak memiliki kekuatan fisik, lemah, emosional, sehingga hanya berhak mengerjakan pekerjaan yang halus, seperti pekerjaan rumah, mengasuh anak, dan lain-lain. Relasi sosial dilakukan atas dasar ukuran laki-laki. ${ }^{2}$

Korban kekerasan biasanya rentan dialami oleh perempuan dan anak. Berbeda halnya dengan korban KDRT adalah orang yang mengalami kekerasan dan/atau ancaman kekerasandalam lingkup rumah tangga. Lingkup rumah tangga, tidak hanya suami, isteri dan anak, tetapi mencakup orang-orang yang tinggal dan menetap dalam rumah tersebut seperti, orang tua dari pihak suami atau isteri. Mereka yang dipandang sebagai anggota keluarga termasukorang yang bekerja membantu rumah tangga dan menetap dalam jangka waktu selama berada dalam rumah tangga yang bersangkutan. ${ }^{3}$

Padahal dalam kehidupan manusia pastinya membutuhkan rasa kasih dan sayang dari seseorang. Untuk memenuhi hal tersebut maka peran seorang pasangan sangatlah dibutuhkan. Dengan adanya seorang pasangan disamping kita maka dalam menjalani kehidupan tidak ada rasa kesepian karena ada sosok orang disamping kita yang selalu menemani dan tenpat berbagi baik suka maupun duka dalam hubungan tersebut salah satunya perkawinan. Perkawinan sendiri merupakan babak baru bagi individu dalam suatu keluarga yang harmonis dalam menjalankan hidup berkeluarga tentunya tidak semulus yang dibayangkan, pasti banyak lika liku masalah dalam keluarga tersebut. Disisi lain ada keluarga yang merasa frustasi dan kurang bijak dalam sikap sehingga masalah tersebut menjadi hal yang sangat besar yang kemudian

1 Moerti Hadiati Soeroso, Kekerasan Dalam Rumah Tangga Dalam Perspektif YuridisViktimologis, Sinar Grafika, Jakarta, 2011, hlm. xiii.

2 http://ditjenpp.kemenkumham.go.id/hukum-pidana/647-kekerasan-dalam-rumah-tanggakdrt-persoalan-privat-yang-jadi-persoalan-publik.html

3 Sahuri Lasmadi, dkk, Tindakan Diskresi Oleh Penyidik Dalam Penyelesaian Tindak Pidana Kekerasan Dalam Rumah Tangga di Polres Tanjung Jabung Barat, Jurnal Sosio Humaniora, Volume 3 Nomor 2, LPPM Universitas Jambi, 2019, hal. 140. 
berujung pada tindak kekerasan dalam rumah tangga yang dilakukan pada anggota keluarga tersebut. Sementara itu argumen rasional berdasar data lengkap tentang berbagai segi dari karakteristik lelaki atau perempuan, mungkin dapat memuaskan logika, tetapi mungkin terasa kering, karena pernikahan bukan semata masalah logika, tetapi justru lebih merupakan masalah perasaan. ${ }^{4}$

Perempuan sering menjadi korban kekerasan karena seksualitasnya sebagai seorang perempuan, banyak hasil penelitian dan kenyataan dalam kehidupan seharihari yang menunjukkan bagaimana lemahnya posisi perempuan ketika mengalami kekerasan terhadap dirinya. Termasuk juga anak-anak sangat rentan terhadap kekerasan yang dilakukan oleh orang-orang disekitarnya. Kekerasan yang terjadi di lingkungan rumah sendiri disebabkan karena penyelesaian permasalahan keluarga.

Tindak KDRT di Indonesia dalam rentang waktu yang panjang cenderung bersifat latenhingga jarang terungkap ke permukaan. Akibatnya, ia lebih merupakan kejadian sederhana yang kurang menarik ketimbang sebagai fakta sosial yang seharusnya mendapatkan perhatian khusus dan penanangan yang sungguh-sungguh dari masyarakat dan pemerintah. ${ }^{5}$

Segala bentuk kekerasan terhadap perempuan merupakan pelanggaran HAM dan kejahatan terhadap eksistensi kemanusiaan serta merupakan bentuk diskriminasi yang harus dihapus karena tidak sesuai dengan deklarasi PBB tentang HAM dan Konvensi Internasional tentang penghapusan segala bentuk diskriminasi terhadap perempuan. ${ }^{6}$

Pada tahun 2004 merupakan tahun terobosan karena Untuk menanggulangi kekerasan dalam rumah tangga tersebut tepatnya pada tanggal 22 September tahun 2004, maka lahirlah undang-undang yang khusus mengatur kekerasan dalam rumah tangga yang terjadi dalam masyarakat yaitu Undang-Undang Nomor 23 Tahun 2004 Tentang Penghapusan Kekerasan Dalam Rumah Tangga.

Secara filosofis, pembentukan Undang-Undang PKDRT untuk melindungi wanita atau ibu rumah tangga dari kekerasan dalam rumah tangga. ${ }^{7}$ UU PKDRT menyebutkan bahwa kasus kekerasan dalam rumah tangga adalah segala jenis kekerasan fisik maupun psikis yang dilakukan oleh anggota keluarga yang lain yang dapat dilakukan oleh suami terhadap istri dan anaknya, atau oleh ibu kepada anaknya, atau bahkan sebaliknya. Meskipun demikian korban yang dominan adalah kekerasan terhadap istri dan anak oleh suami. Kekerasan dalam rumah tangga dapat menimpa siapa saja termasuk ibu, bapak, istri, anak atau pembantu rumah tangga.

Kekerasan dalam rumah tangga menurut Pasal 1 (satu) Undang-Undang Nomor 23 Tahun 2004 Tentang Penghapusan Kekerasan Dalam Rumah Tangga adalah:

4 M. Thoriq Nurmadiansyah, Membina Keluarga Bahagia Sebagai Upaya Penurunan Kekerasan Dalam Rumah Tangga (KDRT) Dalam Perspektif Agama Islam Dan Undang-Undang, hal. 224. http://ejournal.uin-suka.ac.id/pusat/MUSAWA/article/viewFile/102-04/753

5 Sabungan Sibarani, Prospek Penegakan Hukum Undang-Undang Penghapusan Kekerasan Dalam Rumah Tangga (KDRT) https://ejournal.balitbangham.go.id/index.php /ham/article/ download/66/13

6 Elly Sudarti, Syofyan Nur, dkk, Penyuluhan Hukum Tentang Kekerasan Dalam Rumah Tangga (KDRT) Kepada Anggota Polisi Dan Penyidik Di Kepolisian Resort (POLRES) Kabupaten Tanjung Jabung Barat, Jurnal Abdi Masyarakat, LPPM Universitas Jambi, Volume 3 Nomor 2, 2019, hal. 193.

7 Rodliyah, Salim HS, Hukum Pidana Khusus Unsur Dan Sanksi Pidananya, Raja Grafindo Persada, Depok, 2017, hal. 242. 
Setiap perbuatan terhadap seseorang terutama perempuan yang berakibat timbulnya kesengsaraan atau penderitaan fisik, seksual, psikologis dan atau penelantaran rumah tangga termasuk ancaman untuk melakukan perbuatan, pemaksaan atau perampasan kemerdekaan secara melawan hukum (onrechtmagtigedaad) dalam lingkup rumah tangga.

Dari ketentuan dalam Undang-Undang Nomor 23 Tahun 2004 tersebut bahwa cukup jelas mengenai jenis tindak pidana kekerasan dalam rumah tangga yang diatur pada Pasal 5 undang-undang tersebut yang mana ditentukan bahwa:

Setiap orang dilarang melakukan kekerasan dalam rumah tangga terhadap orang dalam lingkup rumah tangganya dengan cara:

a. Kekerasan fisik;

b. Kekerasan psikis;

c. Kekerasan seksual; atau

d. Penelantaran dalam rumah tangga.

Kekerasan dalam rumah tangga sebelum adanya Undang-Undang Nomor 23 Tahun 2004 tentang Penghapusan Kekerasan Dalam Rumah Tangga, korban atau keluarga baru melapor kekerasan yang terjadi setelah mengalami luka parah atau bahkan telah meninggal. Perbuatan pidana tersebut biasanya dituntut dengan Pasal 351 KUHP tentang penganiayaan atau penganiayaan yang menyebabkan matinya korban Pasal 351 ayat (3) KUHP. Kasus tersebut hanya digolongkan pada perbuatan pidana biasa, bukan merupakan delik khusus yaitu kekerasan dalam rumah tangga. ${ }^{8}$

Dengan perkembangannya Indonesia telah memiliki aturan khusus tentang kekerasan dalam rumah tangga yaitu Undang-Undang Nomor 23 Tahun 2004 Tentang Penghapusan Kekerasan Dalam Rumah Tangga. Dengan lahirnya Undang-Undang Nomor 23 Tahun 2004 tentang Penghapusan Kekerasan Dalam Rumah Tangga, maka segala bentuk tindak kekerasan yang terjadi dalam lingkup rumah tangga bukan hanya urusan suami istri tetapi sudah menjadi urusan public, keluarga dan masyarakat dekat ikut mencegah dan mengawasi bila terjadi kekerasan dalam rumah tangga dankekerasan yang terjadi dapat ditangani berlandaskan pada undang-undang yang baru tersebut. Proses penanganannya seperti pada kasus-kasus yang lain, korban atau keluarga/masyarakat melaporkan tentang tindak kekerasan yang terjadi, seperti yang diatur dalam Pasal 15 Undang-Undang Nomor 23 tahun 2004:

Setiap orang yang mendengar, melihat atau mengetahui terjadinya kekerasan dalam rumah tangga wajib melakukan upaya-upaya sesuai dengan batas kemampuannya untuk:

a. Mencegah berlangsungnya tindak pidana;

b. Memberikan perlindungan kepada korban;

c. Memberikan pertolongan darurat; dan

d. Membantu proses pengajuan permohonan penetapan perlindungan.

Jika suatu undang-undang yang baru sebagian menguntungkan dan sebagian tidak menguntungkan terdakwa, maka harus diperbandingkan tiap-tiap undangundang untuk keseluruhannya. Praktik penegakan hukum yang bersifat diskriminatif dan inkonsisten tersebut menimbulkan disparitas pidana, ketidakadilan serta ketidakpastian hukum. Kondisi tersebut disebabkan oleh adanya ketidaksamaan persepsi diantara aparat penegak hukum (ketidaksinkronan kultural) tentang asas lex specialis derogat legi generali, tentang ketentuan hukum pidana khusus, serta model surat dakwaan dalam menerapkan asas tersebut. Kondisi ini tidak dapat dibiarkan,

$8 \quad$ Ibid., hlm. 36. 
karena berakibat pada ketidakpercayaan masyarakat terhadap penegakan hukum. Kondisi ini juga menghambat terwujudnya sistem peradilan pidana terpadu karena salah satu karakteristik dari sistem peradilan pidana terpadu (integrated criminal justice system) adalah sinkronisasi, baik sinkronisasi struktural, subtansial, maupun kultural. ${ }^{9}$

Tindak pidana kekerasan dalam rumah tangga ada yang tergolong delik biasa (umum) dan delik aduan. Hal ini terdapat pada Bab VIII tentang ketentuan pidana dalam Pasal 44, Pasal 45, dan Pasal 46 Undang-Undang Nomor 23 Tahun 2004, yang menyebutkan:

\section{Pasal 44}

(1) Setiap orang yang melakukan perbuatan kekerasan fisik dalam lingkup rumah tangga sebagaimana dimaksud dalam Pasal 5 huruf a dipidana dengan penjara paling lama 5 9lima0 tahun atau denda paling banyak Rp 15.000.000,- (lima belas juta rupiah).

(2) Dalam hal perbuatan sebagaimana dimaksud pada ayat (1) mengakibatkan korban mendapat jatuh sakit atau luka berat, dipidana dengan pidana penjara paling lama 10 (sepuluh) tahun atau denda paling banyak Rp 30.000.000,- (tiga puluh juta rupiah).

(3) Dalam hal perbuatan sebagaimana dimaksud pada ayat (2) mengakibatkan matinya korban, dipidana dengan pinda penjara paling lama 15 (lima belas) tahun atau denda paling banyak Rp 45.000.000,- (empat puluh lima juta rupiah).

(4) Dalam ha perbuatan sebagaimana dimaksud dalam ayat (1) dilakukan oleh suami terhadap isteri atau sebaliknya yang tidak menimbulkan penyakit atau halangan untuk menjalankan pekerjaan jabatan atau mata pencarian atau kegiatan sehari-hari, dipidana dengan pidana penjara paling lama 4 (empat) bulan atau denda paling banyak Rp 5.000.000,- (lima juta rupiah).

\section{Pasal 45}

(1) Setiap orang yang melakukan perbuatan kekerasan psikis dalam lingkup rumah tangga sebagaimana dimaksud pada Pasal 5 huruf b dipidana dengan pidana penjara paling lama 3 (tiga) tahun atau denda paling banyak Rp 9.000.000,- (sembilan juta rupiah).

(2) Dalam hal perbuatan sebagaimana dimaksud pada ayat (1) dilakukan oleh suami terhadap isteri atau sebaliknya yang tidak menimbulkan penyakit atau halangan untuk menjalankan pekerjaan jabatan atau mata pencarian atau kegiatan sehari-hari, dipidana penjara paling lama 4 (empat) bulan atau denda paling banyak Rp 3.000.000,- (tiga juta rupiah).

\section{Pasal 46}

Setiap orang melakukan perbuatan kekerasan seksual sebagaimana dimaksud pada Pasal 8 huruf a dipidana dengan pidana penjara paling lama 12 (dua belas) tahun atau dena paling banyak Rp 36.000.000,- (tiga puluh enam juta rupiah).

Bentuk kekerasan fisik dalam rumah tangga di mana kebanyakan isteri yang menjadi korban antara lain dipukul, ditampar, diludahi, dilepar dengan barang seperti piring, dijambak rambutnya dan ditendang. Kekerasan psikologis yaitu kekerasan yang dialami oleh orang yang dalam lingkup rumah tangga yang tidak menimbulkan bekas seperti kekerasan fisik. Namun kekerasan psikologis dapat meruntuhkan harga diri dari orang yang ada dalam lingkup rumah tangga, menekan

9 Muladi, Kapita Selekta Sistem Peradilan Pidana, Penerbit Undip, Semarang, 1998, hlm. 4. 
batin bahkan memicu dendam. Korban kekerasan dalam rumah tangga yang berbentuk kekerasan psikologis lebih sulit diatasi dari pada korban kekerasan fisik. Kekerasan psikologis adalah "dalam bentuk caci maki, kata-kata kasar, ancaman, pengabaian, penolakan dan penuduhan. ${ }^{10}$

Berdasarkan hal tersebut di atas maka sangat relevan untuk mengkaji lebih jauh mengenai penerapan hukum pidana materil mengenai "Analisis Kasus Tindak Pidana Kekerasan dalam Rumah Tangga"., dalam artikel ini.

\section{B. Metode Penelitian}

Metode yang digunakan dalam penelitian ini adalah yuridis normatif. . Penelitian Yuridis Normatif adalah suatu proses untuk menemukan aturan hukum, prinsipprinsip hukum dan doktrin-doktrin hukum. Penelitian hukum normatif dapat dilakukan terutama terhadap bahan hukum primer dan sekunder, sepanjang bahanbahan itu mengandung kaidah-kaidah hukum.

\section{Pembahasan}

\section{Penerapan Hukum dalam Kasus Kekerasan Dalam Rumah Tangga (Studi Kasus Putusan Nomor : 146/Pid.Sus/2017/PN.Srl)}

Sebelum membahas mengenai penerapan hukum di dalam kasus kekerasan dalam rumah tangga maka perlu diketahui kekerasan dalam rumah tangga bukanlah persoalan domestik (privat) yang tidak boleh diketahui orang lain. Kekerasan dalam rumah tangga merupakan pelanggaran hak asasi manusia dan kejahatan terhadap martabat kemanusiaan serta bentuk diskriminasi yang harus dihapuskan. UndangUndang Nomor 23 Tahun 2004 Tentang Penghapusan Kekerasan Dalam Rumah Tangga ini merupakan jaminan yang diberikan negara untuk mencegah terjadinya kekerasan dalam rumah tangga, menindak pelaku kekerasan dalam rumah tangga, dan melindungi korban kekerasan dalam rumah tangga. ${ }^{11}$

Keberadaan Kitab Undang-Undang Hukum Pidana (KUHP) dan Undang-Undang Penghapusan Kekerasan Dalam Rumah Tangga yaitu Undang-Undang Nomor 23 Tahun 2004 menjadi suatu bagian aturan yang tidak dapat dipisahkan, dimana dalam konsep hukum pidana dikenal sebagai aturan khusus dan aturan umum. Dalam konsepnya, dalam hal penggunaan hukumnya dikenal dengan asas: "aturan hukum yang khusus mengenyampingkan aturan yang umum" atau dikenal dengan asas "Lex specialis derogate lex generalis". Oleh karena itu dapat ditarik gambaran bahwa dalam konsep pengaturan kekerasan dalam rumah tangga tersebut khususnya dalam hal ini yaitu kekerasan fisik di dalam rumah tangga, KUHP menjadi konsep pengaturan umum, sedangkan sebaliknya undang-undang penghapusan kekerasan dalam rumah tangga yaitu Undang-Undang Nomor 23 Tahun 2004 menjadi konsep hukum khusus yang mengatur persoalan tersebut secara khusus. ${ }^{12}$

Dengan melakukan tindak pidana kekerasan fisik yang dilakukan oleh suami terhadap isteri jelas pelakunya dapat dijatuhi pidana dengan aturan yang dilanggarnya, namun sebelum adanya keputusan hakim yang memimpin sidang perkara, tersangka tidak dapat dikatakan murni bersalah.

10 Nys. Arfa, Analisis Yuridis Terhadap Tindak Pidana Kekerasan Seksual Dalam Rumah Tangga Menurut Undang-Undang Nomor 23 Tahun 2004 Tentang Kekerasan Dalam Rumah Tangga Jurnal I novatif, Volume VII Nomor II Mei 2014, hlm. 50

11 Ibid, hlm. 47

12 Ibid, hlm. 48-49 
Seperti halnya dalam kasus ini dimana penerapan hukum yang dikenakan kepada terdakwa MOHD. HERI BIN M. ZEN yang melakukan kekerasan fisik terhadap istri sirrinya yang dikenakan dengan Pasal 351 Ayat (3) KUHP. Oleh jaksa penuntut umum dituntut dengan 2 (dua) tahun penjara. Kemudian dijatuhkan hukuman oleh hakim karena terbukti dan meyakinkan melakukan penganiayaan yang mengakibatkan mati. Padahal, jika dikaitkan dengan asas "lex spesialis derogate lex generalis" harusnya kepada terdakwa dikenakan dengan Pasal yang ada di atur dalam Undang-Undang Nomor 23 tahun 2004 Tentang Penghapusan Kekerasan Dalam Rumah Tangga pada Pasal 44 Ayat (3).

\section{- Krolonologis Kejadian}

Bahwa terdakwa MOHD. HERI BIN M. ZEN, pada hari Sabtu tanggal 22 April 2017 sekira pukul 20.30 WIB atau setidak tidaknya pada waktu lain dalam bulan April 2017 atau setidak-tidaknya dalam tahun 2017 bertempat di rumah orang tua terdakwa di RT. 02 Desa Sungai Baung Kec. Sarolangun Kab. Sarolangun Provinsi Jambi, atau setidak-tidaknya di suatu tempat yang masih termasuk dalam daerah hukum Pengadilan Negeri Sarolangun, telah melakukan Kekerasan Fisik dalam Lingkup Rumah Tangga yang mengakibatkan matinya korban yakni korban NUR ASIAH BINTI NURDIN, perbuatan mana dilakukan Terdakwa dengan cara-cara sebagai berikut:

Bahwa pada hari dan tanggal sebagaimana tersebut diatas sekira pukul 17.30 WIB, terdakwa dan korban NUR ASIAH BINTI NURDIN serta anak tiri terdakwa Sdr. M.ROUF BIN M. RIDHO ROMADHON pergi ke rumah orang tua terdakwa di Desa Sungai Baung Kec. Sarolangun Kab. Sarolangun, selanjutnya setelah sampai di rumah orang tua terdakwa, langsung ngobrol dan makan dengan orang tua terdakwa. Kemudian, sekira pukul 20.30 WIB, terdakwa mengajak korban untuk tidur di rumah orang tua terdakwa, namun pada saat itu korban menolak dengan alasan tidak membawa pakaian, karena mendengar penolakan tersebut membuat terdakwa langsung menjadi emosi dan langsung menarik tangan korban ke dalam kamar, sampai di kamar terdakwa langsung mencekik korban hingga korban terjatuh lalu membekap mulut korban, saat itu korban langsung menjerit dan memberontak lalu terdakwa langsung memukul korban di bagian wajah sebanyak 5 (lima) kali, saat korban dipukul oleh terdakwa, anak tiri dari terdakwa Sdr. M. ROUF BIN M. RIDHO ROMADHON memukul terdakwa dari belakang tetapi terdakwa langsung mendorong Sdr. M. ROUF BIN M. RIDHO ROMADHON hingga jatuh ke lantai, saat itu korban berhasil melarikan diri dan langsung keluar rumah sambil membawa anaknya.

Berdasarkan hasil Visum Et Repertum Nomor : 812/151/VER/ RSUD.SRL/ 2017 tanggal 17 Mei 2017 yang dibuat dan ditandatangani oleh dr. JESILIANI, dokter pemerintah pada Rumah Sakit Umum Daerah Chatib Quzwain, telah dilakukan pemeriksaaan terhadap korban NUR ASIAH BINTI NURDIN, dengan hasil pemeriksaan sebagai berikut:
a. Kepala : - Memar pada kelopak mata kanan atas dan bawah sampai ke pipi
- Pendarahan pada mata sebelah kanan (sub Kunjungtiva bleeding).
- Memar pada dagu sebelah kanan dengan diameter 0,5 cm.
b. Dada : Tidak ada kelainan.
c. Perut : Tidak ada kelainan. 
d. Anggota Gerak Atas : - Memar pada lengan atas kiri bagian depan dengan ukuran $4,5 \times 2 \mathrm{~cm}$

- Memar pada lengan bawah kiri bagian belakang dengan ukuran 1 x $1 \mathrm{~cm}$

- Bengkak dan memar pada punggung tangan kiri dengan ukuran $3,5 \times 3 \mathrm{~cm}$

e. Anggota Gerak Bawah : luka lecet pada paha bawah samping kanan dengan ukuran $5,5 \times 0,5 \mathrm{~cm}$

\section{Kesimpulan pemeriksaan:}

Perdarahan pada mata kanan, bengkak, memar dan luka lecet yang dialami korban di duga disebabkan oleh karena trauma benda tumpul.

- Korban Nur Asiah Binti Nurdin dan terdakwa telah terjadi pernikahan pada tanggal 8 April 2017 di Rt 14 Desa Lubuk Sepuh Kec. Pelawan Kab. Sarolangun.

- Surat Keterangan Kematian dari Plt Kepala Desa Lubuk Sepuh Nomor :007/PemLs/08/2017 menerangkan bahwa korban Nur Asiah binti Nurdin meninggal dunia pada hari Senin tanggal 24 April 2017.

\section{Dasar Hakim Menerapkan Pasal 351 Ayat (3) KUHP dan Bukan Undang- Undang No. 23 tahun 2004 Pasal 44 Ayat (3)}

Hakim menerapkan Pasal 351 ayat (3) KUHP dalam kasus putusan Nomor 146/Pid.Sus/2017/PN.Srl, dengan memperhatikan fakta-fakta yang ada di dalam persidangan, yaitu:

1. Fakta Yuridis

Jaksa Penuntut Umum mendakwa terdakwa MOHD. HERI BIN M. ZEN terbukti bersalah melakukan Tindak Pidana Melakukan Penganiayaan yang mengakibatkan mati orang sebagaimana diatur dalam dakwaan kedua primair Pasal 351 Ayat (3) KUHP. Selama dalam persidangan tidak ditemukan adanya alasan pembenar maupun alasan pemaaf pada diri Terdakwa atas perbuatannya tersebut oleh karenanya Terdakwa dinyatakan mampu mempertanggung jawabkan perbuatannya tersebut dihadapan hukum dan oleh karena itu Terdakwa akan dinyatakan bersalah dan akan dijatuhi pidana.

Karena terdakwa telah didakwa oleh Penuntut Umum dengan dakwaan yang berbentuk alternatif dan hakim memperhatikan fakta-fakta hukum sehingga penerapan Pasal 44 ayat (3) Undang-Undang Nomor 23 Tahun 2004 tentang Penghapusan Kekerasan Dalam Rumah Tangga tidak terbukti. Selain hal itu tersebut bahwa dakwaan alternatif kedua disusun berbentuk subsideritas, sehingga hakim mempertimbangkan dakwaan primer sebagaimana diatur dalam Pasal 351 ayat (3) KUHP.

2. Fakta Persidangan

Fakta persidangan dalam kasus ini yaitu:

a. Keterangan saksi

Dalam kasus ini saksi yang dihadapkan ada 5 (lima) yakni Siti Rukiah Binti Zainudin (Alm), Hermansyah Bin Zainudin (Alm), Malik Salahudin Bin Muchtar, Dani Purwanto alias Siwak bin M. Arpan, dan Amiati Binti Noto Wibowo (Alm).

b. Keterangan ahli

Menerangkan bahwa pada saat melakukan pemeriksaan terhadap korban/pasien a.n NUR ASIAH Binti NURDIN tersebut kondisi korban yaitu korban datang dalam 
keadaan sudah meninggal dunia, adapun dengan ciri nadi sudah tidak teraba, tekanan darah tidak terukur, nafas sudah tidak ada lagi, dan pupil sudah melebar (dilatasi) maksimal. Berdasarkan hasil VER penyebab korban NUR ASIAH mengalami luka dikarenakan oleh trauma benda tumpul.

c. Keterangan terdakwa

Yang pada pokoknya mengakui perbuatan sebagaimana yang telah dipaparkan di dalam kronologis kejadian. Yang mana terdakwa memang benar telah melakukan kekerasan fisik terhadap korban Nur Asiah.

\section{Fakta Sosiologis}

\section{Hal-hal yang memberatkan :}

- Perbuatan Terdakwa mengakibatkan meninggalnya NUR ASIAH Bin NAZARUDIN

\section{Hal-hal yang meringankan :}

- Terdakwa berlaku sopan selama dipersidangan, mengakui dan menyesali perbuatannya, serta berjanji tidak akan mengulanginya lagi ;

- Terdakwa belum pernah dihukum

Dari uraian di atas maka dapat dilihat bahwa Jaksa Penuntut Umum Kejaksaan Negeri Jambi mendakwa dengan dakwaan melanggar Pasal 351 ayat (3) Kitab UndangUndang Hukum Pidana yang menentukan: "Jika perbuatan itu berakibat matinya orang, maka yang bersalah dipidana dengan pidana penjara selama-lamanya tujuh tahun".

Namun, dalam surat dakwaan yang di buat oleh Jaksa Penuntut Umum ada tiga dakwaan yakni : Pertama, Jaksa menuntut dengan Pasal 44 Ayat (3) UU RI No. 23 Tahun 2004 Tentang Penghapusan Kekerasan Dalam Rumah Tangga Jo Pasal 5 huruf a UU RI No. 23 Tahun 2004 Tentang Penghapusan Kekerasan Dalam Rumah Tangga. Kedua (Primeir), menuntut dengan Pasal 351 Ayat (3) KUHP mengenai penganiayaan yang mengakibatkan matinya orang. Dan Ketiga (Subsideir), menuntut dengan Pasal 351 ayat (1).

Dari dakwaan yang diajukan oleh Jaksa Penuntut Umum harusnya Hakim bisa lebih mempertimbangkan hukuman mana yang tepat dijatuhkan karena dari kasus Kekerasan Dalam Rumah Tangga yang terjadi ini korban nya sampai meninggal dunia. Apabila mengacu pada tindak pidana penganiayaan yang mengakibatkan matinya korban maka ancaman yang dijatuhkan ialah selama-lamanya 7 tahun, sedangkan dalam UU PKDRT ancaman yang dijatuhkan terhadap terdakwa apabila terjadi kekerasan fisik yang mengakibatkan korban meninggal dunia ancaman pidananya ialah 15 (lima belas) Tahun.

Dalam hal ini kecenderungan hakim untuk tidak melakukan penemuan hukum kiranya sangat terlihat. Ketentuan Undang-Undang tidak dapat diterapkan begitu saja, secara langsung pada peristiwanya. Untuk dapat menerapkan ketentuan undangundang yang berlaku umum dan abstrak sifatnya itu pada peristiwa yang konkrit dan khusus sifatnya, ketentuan undang-undang itu harus diberi arti, dijelaskan atau ditafsirkan dan diarahkan atau disesuaikan dengan peristiwanya untuk kemudian baru diterapkan pada peristiwanya. ${ }^{13}$ Sejalan dengan hal tersebut, sejak hukum membuat tradisi untuk dituliskan (writen law), maka pembacaan terhadap teks hukum menjadi

13 Sudikno Mertokusumo, Mengenal Hukum Suatu Pengantar, Cetakan Keempat, Liberty Yogyakarta, 2008, hal. 169. 
masalah yang penting sekali. Sejak pembacaan teks menjadi penting, maka penafsiran terhadap teks hukum tak dapat dihindarkan. ${ }^{14}$

Di dalam Putusan ini pula Tuntutan Jaksa Penuntut Umum yang menuntut terdakwa dengan pidana penjara selama 2 (dua) tahun, dan diputuskan oleh Hakim Pengadilan Negeri Sarolangun dengan pidana penjara selama 1 (satu) tahun dan 2 (dua) bulan. Dalam tulisan ini penjatuhan pidana yang dijatuhkan oleh hakim tersebut terlalu ringan mengingat korbannya telah meninggal dunia. Penulis berpendapat bahwa harusnya penjatuhan pidana yang tepat dijatuhkan pada terdakwa adalah dengan Undang-Undang Pemberantasan Kekerasan Dalam Rumah Tangga karena ancaman pidana di dalam Undang-Undang Pemberantasan Kekerasan Dalam Rumah Tangga setidaknya bisa memberikan efek jera kepada terdakwa mengingat korban telah meninggal dunia. Hal ini sejalan dengan Teori Pemidanaan yaitu Teori Absolut (Pembalasan) yang mana pidana merupakan akibat mutlak yang ada sebagai suatu pembalasan atau tindak pidana yang dilakukan seseorang. Ada pemidanaan karena ada pelanggaran hukum, ini merupakan tuntutan keadilan.

Salah satu sifat yang melekat pada perundang-undangan atau hukum tertulis adalah sifat otoritatif dari rumusan rumusan peraturannya. Namun demikian, pengutaraan dalam bentuk tulisan atau litera scripta itu sesungguhnya hanyalah bentuk saja dari usaha untuk menyampaikan sesuatu ide atau pikiran. Sehubungan dengan hal yang disebut belakangan ini orang pun suka menyebut tentang adanya semangat dari suatu peraturan. ${ }^{15}$

Sehingga sebenarnya hakim perlu menggali kembali semangat yang ada dalam UU PKDRT.

Di dalam kasus ini yang menjadi pertimbangan hakim menjatuhkan menggunakan Pasal 351 Ayat (3) dikarenakan pernikahan antara terdakwa dan korban tidak tercatat atau dengan kata lain nikah sirih. Beberapa pertimbangan tersebut yakni:

a. Pertimbangan Yuridis

Pertimbangan yang bersifat yuridis adalah pertimbangan hakim yang didasarkan pada fakta-fakta yuridis yang terungkap di dalam persidangan. Adapun pertimbangan hakim yang digolongkan sebagai pertimbangan yuridis secara sistematis akan diuraikan sebagai berikut:

\section{Dakwaan Jaksa Penuntut Umum}

Perumusan dakwaan berdasarkan atas hasil pemeriksaan dalam putusan 146/Pid.Sus/2017/PN.Srl, Jaksa Penuntut Umum menuntut terdakwa dengan dakwaan alternatif yaitu melanggar Pasal 351 ayat (3) Kitab Undang-Undang Hukum Pidana.

b. Pertimbangan Fakta di Persidangan

Di dalam tulisan ini berdasarkan fakta-fakta yang terungkap di persidangan terdapat kesesuaian antara keterangan terdakwa, keterangan saksi dan juga alat bukti yang terungkap dipersidangan sehingga perkara tersebut telah terbukti secara sah dan meyakinkan telah melakukan tindak pidana penganiayaan karena tidak ditemukan alasan pemaaf dan pembenar, sehingga terhadap terdakwa pada perkara ini dapat dijatuhi pidana.

14 Satjipto Rahardjo, Hukum Dalam Jagat Ketertiban, UKI Press, 2006, hal. 163.

15 Satjipto Rahardjo, Ilmu Hukum, Cetakan Keenam, Citra Aditya Bakti, 2006, hal. 93. 
c. Pertimbangan Sosiologis

Pertimbangan hakim ini terdiri atas dua hal yaitu hal-hal yang memberatkan dan hal-hal yang meringankan bagi terdakwa. Hal-hal yang memberatkan adalah merupakan sesuatu yang menjadi alasan sehingga sanksi yang dijatuhkan kepada terdakwa harus menimbulkan efek jera ataupun menambahkan pidana yang dituntut oleh jaksa penuntut umum kepada terdakwa yang dikarenakan terdakwa tidak adanya alasan yang meringankan baginya. Sedangkan hal yang meringankan bagi terdakwa adalah setiap hal yang menjadi alasan bagi hakim agar sanksi yang didakwakan dikurangi oleh hakim dikarenakan pada diri terdakwa terdapat banyak hal yang meringankan bagi dirinya.

Hakim dalam hal menjatuhkan pidana terhadap terdakwa dengan menggunakan pasal yang ada terdapat di dalam KUHP yakni pasal tentang penganiayaan yaitu pada Pasal 351 ayat (3) karena jika menurut hukum positif indonesia pernikahan yang tidak tercatat apabila terjadi Kekerasan Dalam Rumah Tangga terhadap terdakwanya tidak bisa di jerat dan dikenakan dengan pasal yang ada dalam Undang-Undang Pemberantasan Kekerasan Dalam Rumah Tangga yaitu Undang-Undang Nomor 23 Tahun 2004 dan tidak mendapat perlindungan hukum.

Melihat kenyataan di atas maka sudah seharusnya patut dikaji kembali sistem peradilan pidana harus dilihat dari optik kepentingan yang lebih luas bukan saja hanya menekankan pada kepentingan tersangka atau terdakwa saja namun juga secara menyeluruh termasuk kepentingan korban tindak pidana.

Dari kasus pada tulisan ini dimana telah terjadi tindakan kekerasan dalam rumah tangga yang mengakibatkan korban meninggal dunia dan kemudian oleh Hakim dijatuhkan dengan Pasal tentang Penganiayaan yakni Pasal 351 ayat (3). Hakim memilih aturan dalam KUHP, tentu memiliki pertimbangan pertimbangan tertentu. Ketidakyakinan hakim pada terpenuhinya rumusan dalam aturan penghapusan kekerasan dalam rumah tangga, setidaknya memunculkan argumen bahwa teks undang-undang bukanlah ditafsirkan secara kaku.

"Cara berhukum yang progresif menolak keterikatan pada teks peraturan secara kaku, melainkan menyerahkannya pada perilaku manusianya, tentu saja dalam hal ini adalah perilaku yang baik. Apabila kepentingan manusia dan kemanusiaan menghendaki maka teks peraturan sesungguhnya bisa diabaikan." 16

Sejalan dengan hal tersebut, kedudukan hakim sebagai pembentuk hukum ini berbeda dengan pembentuk undang-undang (legislator). Hakim melalui kuasa pembentukan hukumnya dapat diikuti oleh hakim yang lain. ${ }^{17}$

Dalam tulisan ini juga telah terlihat beberapa putusan mengenai kasus Kekerasan Dalam Rumah Tangga di beberapa daerah di Indonesia yang perkawinannya tidak tercatat akan tetapi terhadap terdakwa dapat dijatuhkan dengan Undang-Undang Pemberantasan Kekerasan Dalam Rumah Tangga yaitu Undang-Undang Nomor 23 Tahun 2004.

16 M. Zulfa Aulia, Hukum Progresif dari Satjipto Rahardjo: Riwayat, Urgensi dan Relevansi, Undang Jurnal Hukum, Fakultas Hukum Universitas Jambi, Volume 1 Nomor 1, 2018, hal. 167. https://ujh.unja.ac.id/index.php/home/article/view/20

17 Budi Suhariyanto, Eksistensi Pembentukan Hukum Oleh Hakim Dalam Dinamika Politik Legislasi Di Indonesia, Jurnal Rechtsvinding, Volume 4 Nomor 3 Desember, hal. 414. 2015. https://rechtsvinding.bphn.go.id/artikel/ART\%205\%20JRV\%204.3\%20WATER.pdf 


\section{Putusan No. 1683/Pid.B/2017 PN Bekasi}

Di dalam putusan ini perkawinan di antara terdakwa dan korban tidaklah tercatat. Kasus Kekerasan Dalam Rumah Tangga yang terjadi di dalam putusan ini pun didakwa oleh Jaksa Penuntut Umum dengan dua dakwaan, yaitu Pertama didakwa dengan Pasal 44 Ayat (1) Undang-Undang Pemberantasan Kekerasan Dalam Rumah Tangga dan Kedua didakwa dengan Pasal 351 Ayat (1) KUHP. Oleh Jaksa Penuntut Umum dituntut dengan Pasal 44 Ayat (1) kemudian oleh Hakim dijatuhkan dengan pidana pada Pasal 44 Ayat (1) Undang-Undang Pemberantasan Kekerasan Dalam Rumah Tangga dengan ancaman hukuman selama 10 (sepuluh) bulan.

\section{Putusan No. 323/Pid.Sus/2016 PN Gorontalo}

Di dalam putusan ini perkawinan antara terdakwa dan korban telah berlangsung selama 20 (dua puluh) tahun namun tidak tercatat dan telah dikaruniai 4 orang anak. Kasus Kekerasan Dalam Rumah Tangga dalam putusan ini di dakwa oleh Jaksa Penuntut Umum dengan dua dakwaan, yaitu Pertama Pasal 44 Ayat (1) UndangUndang Pemberantasan Kekerasan Dalam Rumah Tangga, dan Kedua Pasal 351 Ayat (3). Oleh Jaksa Penuntut Umum dituntut dengan Pasal 44 Ayat (1) dan oleh Hakim menjatuhkan dengan Pasal yang terdapat dalam Undang-Undang Pemberantasan Kekerasan Dalam Rumah Tangga yakni Pasal 44 Ayat (1).

Jika dilihat dari beberapa putusan tersebut di atas, harusnya putusan No.146/Pid.Sus/2017/ PN Sarolangun ini bisa juga dijatuhkan dengan Pasal 44 Ayat (3) yang ada di Undang-Undang Pemberantasan Kekerasan Dalam Rumah Tangga karena status perkawinan tidak tercatat jika terjadi perbuatan yang menimbulkan kesengsaraan secara fisik, seksual, psikis atau penelantaran harusnya bisa dikenakan juga dengan pasal yang ada dalam Undang-Undang Pemberantasan Kekerasan Dalam Rumah Tangga. Karena di dalam tulisan ini bahwa perkawinan yang tidak dicatat adalah perkawinan yang memenuhi Pasal 2 Ayat (1) Undang-Undang Nomor. 1 tahun 1974 Tentang Perkawinan.

\section{Simpulan}

Berdasarkan hasil penelitian dalam tulisan ini dapat disimpulkan beberapa hal yang menyangkut dari pembahasan ini , yaitu: Pertama, Penerapan hukum oleh jaksa penuntut umum di dalam kasus kekerasan fisik yang dilakukan oleh suami terhadap istri yang terjadi di Kabupaten Sarolangun dalam putusan Nomor 146/Pid.Sus/2017/PN.Srl yaitu penerapan pasal yang didakwakan kepada terdakwa tidak sepadan dengan perbuatan yang dilakukan oleh karena telah mengakibatkan korbannya meninggal dunia harusnya terhadap terdakwa bisa dijatuhkan dengan Pasal yang terdapat dalam Undang-Undang Penghapusan Kekerasan Dalam Rumah Tangga. Dalam hal penuntutan, jaksa penuntut umum seharusnya lebih mempertimbangkan perbuatan terdakwa dan akibat yang dialami oleh korban Nur Asiah Binti Nurdin sehingga jaksa penuntut umum dapat menuntut kepada Majelis Hakim agar terdakwa dihukum dengan pidana penjara lebih dari 2 (dua) tahun. Kedua, Dasar hakim menerapkan Pasal 351 ayat (3) KUHP adalah dengan memperhatikan fakta-fakta hukum dipersidangan dan unsur-unsur yang dikenakan serta hakim juga mendengar keterangan-keterangan saksi serta keterangan saksi ahli dan termasuk keterangan terdakwa. Dari fakta persidangan Jaksa Penuntut Umum mendakwa terdakwa dengan Pasal 351 ayat (3) KUHP, terdakwa telah melakukan penganiayaan yang mengakibatkan matinya korban. 


\section{DAFTAR PUSTAKA}

\section{Dokumen Hukum}

Kitab Undang-Undang Hukum Pidana

Republik Indonesia, Undang-Undang Tentang Kekerasan Dalam Rumah Tangga, Nomor 23 Tahun 2004

\section{BUKU}

Moerti Hadiati Soeroso, Kekerasan Dalam Rumah Tangga Dalam Perspektif YuridisViktimologis, Sinar Grafika, Jakarta, 2011.

Muladi, Kapita Selekta Sistem Peradilan Pidana, Penerbit Undip, Semarang, 1998.

Rodliyah, Salim HS, 2017, Hukum Pidana Khusus Unsur Dan Sanksi Pidananya, Raja Grafindo Persada, Depok.

Satjipto Rahardjo, 2006, Ilmu Hukum, Cetakan Keenam, Citra Aditya Bakti.

Satjipto Rahardjo, 2006, Hukum Dalam Jagat Ketertiban, UKI Press.

Sudikno Mertokusumo, 2008, Mengenal Hukum Suatu Pengantar, Cetakan Keempat, Liberty Yogyakarta.

JURNAL

Budi Suhariyanto. Eksistensi Pembentukan Hukum Oleh Hakim Dalam Dinamika Politik Legislasi Di Indonesia, Jurnal Rechtsvinding, Vol. 4, No. 3, Desember, 2015. https://rechtsvinding.bphn.go.id/ artikel/ART\%205\%20JRV\% 204.3\% 20WATER.pdf.

Elly Sudarti, Syofyan Nur, dkk, 2019, Penyuluhan Hukum Tentang Kekerasan Dalam Rumah Tangga (KDRT) Kepada Anggota Polisi Dan Penyidik Di Kepolisian Resort (POLRES) Kabupaten Tanjung Jabung Barat, Jurnal Abdi Masyarakat, LPPM Universitas Jambi, Vol. 3, No. 2. https://onlinejournal.unja.ac.id/JKAM/article/view/8484

M. Thoriq Nurmadiansyah, Membina Keluarga Bahagia Sebagai Upaya Penurunan Kekerasan Dalam Rumah Tangga (KDRT) Dalam Perspektif Agama Islam Dan Undang-Undang. http:// ejournal.uin-suka.ac.id/pusat/MUSAWA/ article/ viewFile/ 102-04/ 753.

M. Zulfa Aulia, 2018, Hukum Progresif dari Satjipto Rahardjo: Riwayat, Urgensi dan Relevansi, Undang Jurnal Hukum, Fakultas Hukum Universitas Jambi, Volume 1 Nomor 1, https://ujh.unja.ac.id/index.php/home/article/view/20

Nys. Arfa, Analisis Yuridis Terhadap Tindak Pidana Kekerasan Seksual Dalam Rumah Tangga Menurut Undang-Undang Nomor 23 Tahun 2004 Tentang Kekerasan Dalam Rumah Tangga Jurnal I Novatif Vol. 7, No. 2, Mei 2014. 
Sahuri Lasmadi, et al. 2019, Tindakan Diskresi Oleh Penyidik Dalam Penyelesaian Tindak Pidana Kekerasan Dalam Rumah Tangga di Polres Tanjung Jabung Barat, Jurnal Sosio Humaniora, Vol. 3, No. 2, LPPM Universitas Jambi. https://online-journal.unja.ac.id/JSSH/article/view/8118.

\section{Website}

http://ditjenpp.kemenkumham.go.id/hukum-pidana/647-kekerasan-dalam-rumahtangga-kdrt-persoalan-privat-yang-jadi-persoalan-publik.html.

Sabungan Sibarani, Prospek Penegakan Hukum Undang-Undang Penghapusan Kekerasan Dalam Rumah Tangga (KDRT)https://ejournal.balitbangham.go.id / index.php/ham /article/download/66/13. 